Review

\title{
Vitamin D and Cardiovascular Disease
}

\section{Vivian Cristina Garcia and Lígia Araújo Martini *}

Nutrition Department, School of Public Health, Sao Paulo University, Av. Dr. Arnaldo, 715, Cerqueira César, CEP 01246-904, São Paulo, Brazil; E-Mail: viviangarcia@usp.br

* Author to whom correspondence should be addressed: E-Mail: 1martini@usp.br; Tel.: +55-11-3061-7859.

Received: 26 January 2010; in revised form: 15 March 2010 / Accepted: 19 March 2010 /

Published: 31 March 2010

\begin{abstract}
Vitamin D insufficiency/deficiency has been observed worldwide at all stages of life. It has been characterized as a public health problem, since low concentrations of this vitamin have been linked to the pathogenesis of several chronic diseases. Several studies have suggested that vitamin $\mathrm{D}$ is involved in cardiovascular diseases and have provided evidence that it has a role in reducing cardiovascular disease risk. It may be involved in regulation of gene expression through the presence of vitamin D receptors in various cells, regulation of blood pressure (through renin-angiotensin system), and modulation of cell growth and proliferation including vascular smooth muscle cells and cardiomyocytes. Identifying correct mechanisms and relationships between vitamin D and such diseases could be important in relation to patient care and healthcare policies.
\end{abstract}

Keywords: vitamin D; cardiovascular disease; hypertension

\section{Introduction}

The main function of vitamin D relates to the development and maintenance of bone tissue. It is responsible for maintaining calcium and phosphorus homeostasis. Vitamin D insufficiency/deficiency has been observed worldwide at all stages of life. It has been characterized as a public health problem, since low concentrations of this vitamin has been linked to the pathogenesis of several chronic diseases with cardiovascular risk factors, such as hypertension, heart failure, atherosclerosis and peripheral arterial disease [1-3]. Following the discovery of the presence of vitamin D receptors (VDR) in many 
cells, including cardiomyocytes [4], vascular smooth muscle cells (VSMC) [5] and endothelium [6], several mechanisms have been proposed to explain the relationship between vitamin $\mathrm{D}$ and the development of cardiovascular disease. Such mechanisms include involvement of vitamin D in the angiotensin-renin system [7] and proliferation and growth of VSMC [8].

\section{Physiology of Vitamin D}

Vitamin $\mathrm{D}$ is found as ergocalciferol (vitamin $\mathrm{D}_{2}$ ) produced by plant and as cholecalciferol (vitamin $\mathrm{D}_{3}$ ) produced by animal tissue. It is also produced by exposure to ultraviolet-B (290 to $310 \mathrm{~nm}$ ) in 7dehydrocholesterol, which is present in human skin [9]. It has been estimated that $80-90 \%$ of vitamin $\mathrm{D}$ is acquired by means of cutaneous synthesis and the remainder through the diet [10]. Vitamin D prohormone is biologically inactive, and it becomes active through conversion to its major form 25hydroxyvitamin D $(25(\mathrm{OH}) \mathrm{D})$ in the liver: this metabolite is used to classify vitamin D status. Following this, the hormonal form of vitamin D (1,25-dihydroxyvitamin D [1,25(OH $\left.)_{2} \mathrm{D}_{3}\right]$ or calcitriol) is produced in other tissues like prostate, breast, colon and especially the kidneys, through 1-alphahydroxylase $[9,10]$. This metabolite production is controlled by the serum parathyroid hormone (PTH), calcium and phosphorus concentrations.

The effects of $1,25(\mathrm{OH})_{2} \mathrm{D}_{3}$ are mediated by VDR, which are present in many cells. At the nucleus of the target cells, $1,25(\mathrm{OH})_{2} \mathrm{D}_{3}$ associated with VDR binds to the retinoic X receptor (RXR), thereby forming heterodimers. These work on vitamin $\mathrm{D}$ response elements, hence initiating the cascade of molecular interactions that will modulate the transcription of the specific gene [11]. Thus, exceedingly low concentrations of $25(\mathrm{OH}) \mathrm{D}$ can result in failure of this metabolic cascade and alter gene expression.

Individuals' vitamin D levels or their nutritional status regarding vitamin D are measured according to the plasma levels of $25(\mathrm{OH}) \mathrm{D}$. The biologically active form of vitamin $\mathrm{D},\left(1,25(\mathrm{OH})_{2} \mathrm{D}_{3}\right)$, is unsuitable for this purpose for reasons such as: a) the rigid maintenance of plasma levels of $1,25(\mathrm{OH})_{2} \mathrm{D}_{3}$ at normal concentrations, even with low plasma concentrations of $25(\mathrm{OH}) \mathrm{D}$ (except in cases of chronic kidney disease and in the presence of high fibroblast growth factor-23 concentrations); b) plasma $25(\mathrm{OH}) \mathrm{D}$ levels are approximately 100-times greater than those of $1,25(\mathrm{OH})_{2} \mathrm{D}_{3}$; and c) hydroxylation of $25(\mathrm{OH}) \mathrm{D}$ to $1,25(\mathrm{OH})_{2} \mathrm{D}_{3}$ occurs in various tissues, thereby covering local needs [12].

In 2005, Hollis [13] considered that the optimal level of vitamin D would be that required to maintain parathyroid hormone (PTH) at appropriate levels. It is known that vitamin D deficiency leads to decreased serum calcium, which consequently stimulates the parathyroid glands to release $\mathrm{PTH}$, thereby increasing renal reabsorption and bone calcium levels. In this regard, several studies have found a plateau of calcium absorption and adequate PTH levels, with 25(OH)D levels close to 30 $\mathrm{ng} / \mathrm{mL}(75 \mathrm{nmol} / \mathrm{L})$ [14-18]. However, the adequate levels of $25(\mathrm{OH}) \mathrm{D}$ for non-calcemic disorders has still not been established.

\subsection{Sources of Vitamin D}

Factors such as latitude, season and time of day influence the cutaneous synthesis of vitamin D. During the summer, 7-dehydrocholesterol in the skin is more efficiently converted to previtamin D. 
Cutaneous synthesis of vitamin D is higher in low-latitude regions because of greater exposure to sunlight [19]. The use of sunscreen, the amount of melanin in the skin, types of clothing and high levels of air pollution may reduce skin exposure to UVB and result in decreased synthesis of vitamin D. Another important factor leading to hypovitaminosis D is changes in lifestyle, such as reduction of outdoor activities.

There are limited natural dietary sources of vitamin D. Not all countries have regulations requiring food fortification, and this leads to low consumption. Table 1 demonstrates the vitamin $\mathrm{D}$ content in selected foods. A recent review [20] showed the dietary requirements for adequate vitamin D nutritional status. For example, for $97.5 \%$ of the population aged $20-40$ years, a mean intake during the winter of $8.7 \mu \mathrm{g} / \mathrm{d}$ would be needed in order to achieve $25(\mathrm{OH}) \mathrm{D}$ serum level greater than 25 $\mathrm{nmol} / \mathrm{L}$, and $41.1 \mu \mathrm{g} / \mathrm{d}$ for a $25(\mathrm{OH}) \mathrm{D}$ level of $80 \mathrm{nmol} / \mathrm{L}$. The same dietary requirements have been observed among the elderly [21].

However, studies have demonstrated that several populations do not attain these dietary intake levels [22,23].

Table 1. Vitamin $D_{2}$ and $D_{3}$ content in selected foods, adapted from the USDA national nutrient database for standard reference, Release 22.

\begin{tabular}{|l|c|c|}
\hline Foods (common portion sizes) & \multicolumn{2}{|c|}{ Vitamin D content $(\boldsymbol{\mu g})$} \\
\hline & ${\text { Vitamin } \mathbf{D}_{\mathbf{2}}}$ & ${\text { Vitamin } \mathbf{D}_{\mathbf{3}}}$ \\
\hline Salmon, cooked (155g) & 0.0 & 36.1 \\
\hline Tuna, canned in oil (85g) & 0.0 & 5.7 \\
\hline Sardines (24g) & 0.0 & 4.8 \\
\hline Liver, beef cooked (85g) & 0.0 & 1.0 \\
\hline Top sirloin, beef cooked broiled (85g) & 0.0 & 0.2 \\
\hline Whole milk with vitamin D fortification (244g) & 0.0 & 1.3 \\
\hline Whole milk, without vitamin D (244g) & 0.0 & 0.1 \\
\hline Butter (5g) & 0.0 & 1.5 \\
\hline Mushrooms, portabella, grilled(121g) & 0.3 & 0.0 \\
\hline $\begin{array}{l}\text { Mushrooms, portabella, grilled, exposed to UV } \\
\text { light (121g) }\end{array}$ & 13.1 & 1.0 \\
\hline Mushrooms, shiitake, cooked (72g) & 0.7 & 0.1 \\
\hline $\begin{array}{l}\text { Vegetables (kale, broccoli, spinach, tomato, } \\
\text { carrots and lettuce) (100g) }\end{array}$ & 0.0 & 0.0 \\
\hline
\end{tabular}

\section{Epidemiological and Observational Evidence}

Cardiovascular diseases are the leading cause of death worldwide. According to the World Health Organization (WHO), these diseases affect 17.1 million people around the world and deaths occur 
predominantly in low and middle-income countries, almost equally in men and women. A reduction of 2 to $3 \mathrm{mmHg}$ in systolic blood pressure is associated with a reduction of 10 to $15 \%$ in mortality from cardiovascular disease [24].

Recently, Giovannucci et al. [25] assessed the association between serum 25(OH)D and risk of coronary disease among men who participated in the Health Professionals Follow-up Study. Men with vitamin D deficiency $(\leq 15 \mathrm{ng} / \mathrm{ml}$ or $37 \mathrm{nmol} / \mathrm{L})$ were at significantly increased risk of developing myocardial infarction, compared with those with sufficient levels of vitamin $\mathrm{D}(\geq 30 \mathrm{ng} / \mathrm{mL}$ or 75 nmol/L) (RR 2.09; 95\% CI: 1.24-3.54).

Analyzing the population of NHANES III, Melamed et al. [26] observed that the prevalence ratio of peripheral arterial disease for the lowest $25(\mathrm{OH}) \mathrm{D}$ quartile, compared with the highest quartile $(<44.5$ and $\geq 73.8 \mathrm{nmol} / \mathrm{L}$, respectively) was 1.80 (95\% CI: 1.19-2.74). A similar situation has been observed in other studies $[27,28]$ on the population of NHANES III, evaluating the associations between serum $25(\mathrm{OH}) \mathrm{D}$ and coronary heart disease, heart failure, stroke and peripheral arterial disease.

Comparing vitamin D status among more than 3000 subjects, over a seven-year follow-up period, Pilz et al. [29] found that patients with severe vitamin D deficiency [25(OH)D $<25 \mathrm{nmol} / \mathrm{L}]$ had a risk of dying from heart failure or sudden cardiac death that was three to five times greater than among patients with optimal levels of vitamin $\mathrm{D}[25(\mathrm{OH}) \mathrm{D} \geq 75 \mathrm{nmol} / \mathrm{L}]$. In patients who had already had heart failure, low serum calcitriol concentrations were associated with critical end-stage outcomes [30].

Evaluating data from InCHIANTI, a prospective cohort study on aging, it was observed that participants who were in the lowest quartile of serum $25(\mathrm{OH}) \mathrm{D}(\leq 26.25 \mathrm{nmol} / \mathrm{L})$ were at higher risk of allcause mortality (HR 2.11, 95\% CI: $1.22-3.64, p=0.007)$ and mortality from cardiovascular disease (HR 2.64, 95\% CI: $1.14-4.79, p=0.02)$, compared with those in the highest quartile ( $\geq 66.25 \mathrm{nmol} / \mathrm{L})$ [31].

Among adolescents [32], it was also demonstrated that low 25(OH)D levels were strongly inversely associated with cardiometabolic risk factors (systolic blood pressure and plasma glucose concentrations).

The involvement of vitamin D insufficiency with hypertension has also been demonstrated. Investigating the population over the age of 20 years who participated in NHANES III, Scragg et al. [3] found systolic and diastolic pressures that were respectively 3.0 and $1.6 \mathrm{mmHg}$ lower in highest quintile of $25(\mathrm{OH}) \mathrm{D}(\geq 85.7 \mathrm{nmol} / \mathrm{L})$, compared with the lowest quintile of vitamin $\mathrm{D}(25(\mathrm{OH}) \mathrm{D} \leq$ $40 \mathrm{nmol} / \mathrm{L}$ ). In the Nurses Health Study and the Healthy Professional Follow-up Study, the negative relationship between serum levels of vitamin D and hypertension was also demonstrated [33]. After four years of follow-up, the relative risk for men with low levels of serum 25(OH)D to develop hypertension was 6.13 (95\% CI: 1.00-37.80), while for women it was 2.67 (95\% CI: 1.05-6.97). After eight years of follow-up, the relative risk for men was 3.53 (95\% CI: 1.02-12.3) and for women, 1.7 (95\% CI: 0.92-3.16).

\section{Proposed Mechanisms for Vitamin D in Cardiovascular Disease}

The mechanisms underlying the role of vitamin $\mathrm{D}$ in the prevention of heart disease remain incompletely explained. However, the mechanisms hypothesized involve the presence of VDR in various cells and its possible modulation of the expression of several genes. $1,25(\mathrm{OH})_{2} \mathrm{D}_{3}$ may 
interfere in the cascade of reactions and consequent functional capacity of certain cells. Such mechanisms include vitamin $\mathrm{D}$ as a negative regulator for renin and an inhibitor of cell proliferation and growth.

\subsection{Angiotensin-renin System}

Inappropriate activation of the renin-angiotensin system may represent a major risk factor for hypertension and, consequently, for cardiovascular diseases. Several studies have indicated that serum levels of $1,25(\mathrm{OH})_{2} \mathrm{D}_{3}$ are inversely associated with blood pressure or plasma renin activity in normotensive and hypertensive subjects [34-38]. In a experimental study with wild-type mice, the research group of Yan Chun Li [7] showed that inhibition of $1,25(\mathrm{OH})_{2} \mathrm{D}_{3}$ synthesis led to an increase in renin expression, whereas $1,25(\mathrm{OH})_{2} \mathrm{D}_{3}$ injection led to renin suppression in the juxtaglomerular apparatus, independently of parathyroid hormone and calcium metabolism [39]. The same group [40] also demonstrated, in cell cultures, that $1,25(\mathrm{OH})_{2} \mathrm{D}_{3}$ directly suppressed renin gene transcription by means of a VDR-dependent mechanism. Elucidating this mechanism, a study found that $1,25(\mathrm{OH})_{2} \mathrm{D}_{3}$ suppressed renin gene expression in part by blocking the formation of the cyclic AMP response element [41]. These data suggest that vitamin D analogs and supplements may potentially be agents for controlling renin production and blood pressure.

Corroborating this hypothesis, Fryer et al. [42] evaluated the effects of paricalcitol and calcitriol on renin expression in C57/BL6 mice and showed that paricalcitol produces significant dose-dependent reductions in renin/GAPDH expression and calcitriol produced renin suppression. Additionally, Zhou et al. [43] demonstrated regulation of the renin-angiotensin system through supplementation of $1,25(\mathrm{OH})_{2} \mathrm{D}_{3}$ in 1- $\alpha$ hydroxylase knockout mice free of enzyme.

\subsection{Role of vitamin D in cardiac tissue}

Few in vitro and in vivo studies have evaluated the role of vitamin $\mathrm{D}$ in cardiac tissue. Carthy et al. [8], demonstrated in vitro that $1,25(\mathrm{OH})_{2} \mathrm{D}_{3}$ blocked the proliferation and growth of VSMC. In a recent study on administration of vitamin D analogs in cells cultures, Wu-Wong et al. [5] observed regulation of the expression of IGF1, Wilms tumor 1 and TGFß, which are three genes that are known to modulate cell proliferation. In addition, they observed downregulation of the expression of natriuretic peptide precursor B and thrombospondin 1, which inhibit cell proliferation. However, another study by the same group [44] suggested that elevated phosphorus affects VDR-mediated gene expression in human VSMC, and therefore the effect is not limited to VDR.

Since VSMC is modulated by VDR, some studies have pointed towards its involvement in the endothelium. A study performed to evaluate endothelial function by brachial artery flow mediated dilatation in 23 asymptomatic vitamin $\mathrm{D}$-deficient subjects found a positive correlation between endothelial function and 25(OH)D $(\mathrm{r}=0.45 ; p=0.001)$ [45].

With regard to the action of vitamin D on cardiomyocytes, a study [46] confirmed the presence of VDR, and that $1,25(\mathrm{OH})_{2} \mathrm{D}_{3}$ affected the growth, proliferation and morphology of murine cardiac myocytes (HL-1 cells) in cultures. The cells were treated with $1,25(\mathrm{OH})_{2} \mathrm{D}_{3}$, and increased expression of myotrophin with decreasing expression of atrial natriuretic peptide and c-myc were observed. Furthermore, the $1,25(\mathrm{OH})_{2} \mathrm{D}_{3}$ treatment also increased the expression and nuclear localization of the 
VDR in these cardiomyocytes. Another study [47] showed that $1,25(\mathrm{OH})_{2} \mathrm{D}_{3}$ treatment in a model of hypertensive rats subjected to a high-salt diet resulted in lower heart weight, myocardial collagen levels, left ventricular diameter and cardiac output, thus suggesting that it had an important preventive role in relation to the development of cardiac hypertrophy and consequent congestive heart failure. Corroborating these findings, it was found that paricalcitol supplementation in Dahl salt-sensitive rats that were also fed a high-salt diet attenuated the cardiac hypertrophy [48]. In Sprague-Dawley rats, maternal vitamin D deficiency led to increased left ventricle volume, greater cardiomyocyte numbers and size, and a higher proportion of mononucleated cardiomyocytes in the offspring at four weeks of age [49].

\section{Vitamin D Supplementation Studies}

In 2009, Zittermann et al. [50] conducted a double-blind, placebo-controlled trial in which 12 months of supplementation of $83.3 \mu \mathrm{g}$ of vitamin D was supplied to 200 women who had started a weight reduction program. They found that the group of supplemented women had greater decreases in PTH levels, triacylglycerides and tumor necrosis factor- $\alpha$ (TNF- $\alpha$ ). Another important point was that weight loss did not differ between the vitamin D and placebo groups. Additionally, a study investigated whether vitamin D was associated with cytokine production [51]. It was found that vitamin D supplementation increased the anti-inflammatory cytokine production, such as IL-10, in patients with heart failure.

A study on patients with predialysis chronic kidney disease showed that oral administration of alfacalcidol was associated with reduced risk of cardiovascular disease [52].

However, a randomized, double-blind, placebo-controlled trial on the population of the Women's Health Initiative [53], which was administered $1,000 \mathrm{mg}$ elemental calcium carbonate and $10 \mu \mathrm{g}$ of vitamin $\mathrm{D}_{3}$ daily, or placebo, found no reduction in mortality due to cardiovascular disease, but the hazard ratios trended in the direction of reduced risk. As an incidental finding, the daily amount of vitamin $\mathrm{D}_{3}$ in this study, like in other study using similar amounts of vitamin D supplementation [54], did not find any additional benefits. Furthermore, Bolland et al. [55] reported that calcium supplementation above the recommended levels in specific populations (elderly people or individuals with previous cardiovascular events) might increase the risk of cardiovascular events.

In a double-blind, placebo-controlled study in 1987, Lind et al. [56] observed reductions in the blood pressure of 39 hypertensive patients with vitamin D supplementation. This reduction was also highlighted in another study on older women supplemented with calcium and vitamin D [57]. Another trial observed that administration of $1,25(\mathrm{OH})_{2} \mathrm{D}_{3}$ reduced blood pressure, as well as plasma renin activity and angiotensin II levels [58].

On the other hand, Thierry-Palmer et al. [59] increased the supply of vitamin D in the diet of saltsensitive rats that were administered a high-salt diet and observed an increase in serum $25(\mathrm{OH}) \mathrm{D}$, but their hypertension was not alleviated. These findings could suggest that there is a potential difference in the effects on the vitamin D endocrine system between salt-induced hypertension and essential hypertension.

Table 2 highlights the cardiovascular effects of vitamin D supplementation. 
Table 2. Cardiovascular effects of vitamin D supplementation.

\begin{tabular}{|c|c|c|c|}
\hline Study & Population & $\begin{array}{l}\text { Supplementation } \\
\text { type, dose and period }\end{array}$ & Main outcomes \\
\hline $\begin{array}{l}\text { Kimura et al., } \\
1999[58]\end{array}$ & $\begin{array}{l}\text { Case report on a } 42 \text {-year- } \\
\text { old man. }\end{array}$ & $\begin{array}{l}\text { Oral administration of } \\
0.2 \mu \mathrm{g} \text { of calcitriol }\end{array}$ & $\begin{array}{l}\downarrow \text { blood pressure, plasma } \\
\text { renin activity and levels } \\
\text { of angiotensin II. }\end{array}$ \\
\hline $\begin{array}{l}\text { Pfeifer et al., } \\
2001[57]\end{array}$ & $\begin{array}{l}148 \text { women } 70 \text { years of } \\
\text { age or older ( } 74 \text { patients in } \\
\text { calcium group and } 74 \\
\text { patients in vitamin-D- } \\
\text { calcium group). }\end{array}$ & $\begin{array}{l}1,200 \mathrm{mg} \text { of } \mathrm{CaCO}_{3} \text { or } \\
1,200 \mathrm{mg} \text { of } \mathrm{CaCO}_{3}+ \\
20 \mu \mathrm{g} \text { of } \\
\text { cholecalciferol }\end{array}$ & $\begin{array}{l}\text { In vitamin-D-calcium } \\
\text { group, } \uparrow \text { in } 25(\mathrm{OH}) \mathrm{D} \text { of } \\
72 \% \text { and } \downarrow \text { in serum PTH } \\
\text { of } 17 \% \text {, and in systolic } \\
\text { blood pressure of } 9.3 \% \text {, } \\
\text { heart rate } \downarrow 5.4 \% \text {. }\end{array}$ \\
\hline $\begin{array}{l}\text { Schleithoff et al., } \\
2006[51]\end{array}$ & $\begin{array}{l}123 \text { patients with } \\
\text { congestive heart failure } \\
\text { randomized into } \mathrm{D}(+) \\
\text { group and } \mathrm{D}(-) \text { group }\end{array}$ & $\begin{array}{l}\mathrm{D}(+) \text { group received } \\
50 \mu \mathrm{g} \text { of vitamin } \mathrm{D}_{3}+ \\
500 \mathrm{mg} \text { of } \mathrm{Ca} / \mathrm{d} ; \mathrm{D}(-) \\
\text { group received } \\
\text { placebo }+500 \mathrm{mg} \text { of } \\
\mathrm{Ca} / \mathrm{d} \text { for } 9 \text { months }\end{array}$ & $\begin{array}{l}\text { In } \mathrm{D}(+) \text { group: } \downarrow \mathrm{PTH} \text {, } \\
\uparrow \quad \text { IL-10 and TNF } \\
\text { remained constant. } \\
\text { In } \mathrm{D}(-) \text { group: } \uparrow \mathrm{TNF} \alpha \text {. } \\
\text { Survival rate did not } \\
\text { differ significantly } \\
\text { between groups. }\end{array}$ \\
\hline $\begin{array}{l}\text { Zittermann et al., } \\
2009[50]\end{array}$ & $\begin{array}{l}200 \text { women who started a } \\
\text { weight-loss program ( } 100 \\
\text { patients in vitamin D } \\
\text { group and } 100 \text { patients in } \\
\text { placebo group). }\end{array}$ & $\begin{array}{l}83.3 \mu \mathrm{g} / \mathrm{d} \text { of } \\
\text { cholecalciferol for } 12 \\
\text { months }\end{array}$ & $\begin{array}{l}\downarrow \mathrm{PTH}, \text { triacylglycerides } \\
\text { and TNF } \alpha .\end{array}$ \\
\hline $\begin{array}{l}\text { Sigiura et al., } \\
2009[52]\end{array}$ & $\begin{array}{l}665 \text { patients with } \\
\text { predialysis chronic kidney } \\
\text { disease ( } 107 \text { patients in } \\
\text { alfacalcidol treatment } \\
\text { group and } 558 \text { in non- } \\
\text { treatment group). }\end{array}$ & $\begin{array}{l}0.25-0.5 \mu \mathrm{g} / \mathrm{d} \text { of } \\
\text { alfacalcidol for } \\
24 \text { weeks }\end{array}$ & $\begin{array}{l}\text { Lower incidence of } \\
\text { cumulative cardiovascular } \\
\text { events in alfacalcidol } \\
\text { treatment group. }\end{array}$ \\
\hline $\begin{array}{l}\text { LaCroix et al., } \\
2009 \text { [53] }\end{array}$ & $\begin{array}{l}36,282 \text { participants in } \\
\text { Women's Health Initiative } \\
(18,176 \text { postmenopausal } \\
\text { women in vitamin D group } \\
\text { and } 18,106 \text { in placebo } \\
\text { group). }\end{array}$ & $\begin{array}{l}1,000 \mathrm{mg} \mathrm{CaCO}_{3}+10 \\
\mu \mathrm{g} / \mathrm{d} \text { of cholecalciferol } \\
\text { for } 7 \text { years }\end{array}$ & $\begin{array}{l}\text { No reduction in } \\
\text { cardiovascular mortality. }\end{array}$ \\
\hline
\end{tabular}

\section{Conclusion}

Hypovitaminosis D has been observed worldwide and several studies have demonstrated a strong association between vitamin D status and cardiovascular diseases. There are few food sources of vitamin $\mathrm{D}$, and the lack of food fortification in some countries, associated with low cutaneous synthesis, intensifies vitamin D insufficiency. Moreover, the understanding of the exact mechanisms through which $25(\mathrm{OH}) \mathrm{D}$ or the active form $1,25(\mathrm{OH})_{2} \mathrm{D}_{3}$ regulate the renin-angiotensin system and cell proliferation and growth (such as VSMC and endothelium cells) remains incomplete. In this regard, identifying correct relationships between vitamin D status and cardiovascular disease is an 
important matter that could contribute towards prevention of such diseases. In the meanwhile, health professionals should be aware of the potential negative implications of vitamin D insufficiency and make recommendations for their patients to improve their vitamin D status.

\section{References and Notes}

1. Melamed, M.L.; Michos, E.D.; Post, W.; Astor, B. 25-hydroxyvitamin D levels and the risk of mortality in the general population. Arch. Intern. Med. 2008, 168, 1629-1637.

2. Reis, J.P.; von Mühlen, D.; Michos, E.D.; Miller, E.R., $3^{\text {rd }}$; Appel, L.J.; Araneta, M.R.; BarrettConnor, E. Serum vitamin D, parathyroid hormone levels, and carotid atherosclerosis. Atherosclerosis 2009, 207, 585-590.

3. Scragg, R.; Sowers, M.; Bell, C. Serum 25-hydroxyvitamin D, ethnicity, and blood pressure in the Third National Health and Nutrition Examination Survey. Am. J. Hypertens. 2007, 20, 713-719.

4. Chen, S.; Glenn, D.J.; Ni, W.; Grigsby, C.L.; Olsen, K.; Nishimoto, M.; Law, C.S.; Gardner, D.G. Expression of the vitamin d receptor is increased in the hypertrophic heart. Hypertension 2008, 52, 1106-1112.

5. Wu-Wong, J.R.; Nakane, M.; Ma, J.; Ruan, X.; Kroeger, P.E. Effects of Vitamin D analogs on gene expression profiling in human coronary artery smooth muscle cells. Atherosclerosis 2006, 186, 20-28.

6. Merke, J.; Milde, P.; Lewicka, S.; Hügel, U.; Klaus, G.; Mangelsdorf, D.J.; Haussler, M.R.; Rauterberg, E.W.; Ritz, E. Identification and regulation of 1,25-dihydroxyvitamin D3 receptor activity and biosynthesis of 1,25-dihydroxyvitamin D3. Studies in cultured bovine aortic endothelial cells and human dermal capillaries. J. Clin. Invest. 1989, 83, 1903-1915.

7. Li, Y.C.; Kong, J.; Wei, M.; Chen, Z.F.; Liu, S.Q.; Cao, L.P. 1,25-Dihydroxyvitamin D(3) is a negative endocrine regulator of the renin-angiotensin system. J. Clin. Invest. 2002, 110, 229-238.

8. Carthy, E.P.; Yamashita, W.; Hsu, A.; Ooi, B.S. 1,25-Dihydroxyvitamin D3 and rat vascular smooth muscle cell growth. Hypertension 1989, 13, 954-959.

9. Miller, W.L.; Portale, A.A. Genetic disorders of vitamin D biosynthesis. Endocrinol. Metab. Clin. North Am. 1999, 28, 825-840.

10. Holick, M.F. Evolution, biologic function, and recommended dietary allowances for vitamin D. In Vitamin D: Physiology, Molecular Biology, and Clinical Applications, 1st ed.; Holick, M.F., Ed.; Humana Press: Totowa, NJ, USA, 1999; pp. 1-16.

11. Schuch, N.J.; Garcia, V.C.; Martini, L.A. Vitamin D and endocrine diseases. Arq. Bras. Endocrinol. Metabol. 2009, 53, 625-633.

12. Mosekilde, L. Vitamin D and the elderly. Clin. Endocrinol. 2005, 62, 265-281.

13. Hollis, B.W. Circulating 25-hydroxyvitamin D levels indicative of vitamin D sufficiency: implications for establishing a new effective dietary intake recommendation for vitamin D. $J$. Nutr. 2005, 35, 317-322.

14. Chapuy, M.C.; Preziosi, P.; Maamer, M.; Arnaud, S.; Galan, P.; Hercberg, S.; Meunier, P.J. Prevalence of vitamin D insufficiency in an adult normal population. Osteoporos. Int. 1997; 7 , 439-443. 
15. Dawson-Hughes, B. Racial/ethnic considerations in making recommendations for vitamin $\mathrm{D}$ for adult and elderly men and women. Am. J. Clin. Nutr. 2004, 80, 1763S-1766S.

16. Heaney, R.P. Functional indices of vitamin D status and ramifications of vitamin D deficiency. Am. J. Clin. Nutr. 2004, 80, 1706S-1709S.

17. Tangpricha, V.; Pearce, E.N.; Chen, T.C.; Holick, M.F. Vitamin D insufficiency among free-living healthy young adults. Am. J. Med. 2002, 112, 659-662.

18. Vieth, R.; Ladak, Y.; Walfish, P.G. Age-related changes in the 25-hydroxyvitamin D versus parathyroid hormone relationship suggest a different reason why older adults require more vitamin D. J. Clin. Endocrinol. Metab. 2003, 88, 185-191.

19. Webb, A.R.; Kline, L.; Holick, M.F. Influence of season and latitude on the cutaneous synthesis of vitamin D3: exposure to winter sunlight in Boston and Edmonton will not promote vitamin D3 synthesis in human skin. J. Clin. Endocrinol. Metab. 1988, 67, 373-378.

20. Cashman, K.D.; Hill, T.R.; Lucey, A.J.; Taylor, N.; Seamans, K.M.; Muldowney, S.; Fitzgerald, A.P.; Flynn, A.; Barnes, M.S.; Horigan, G.; Bonham, M.P.; Duffy, E.M.; Strain, J.J.; Wallace, J.M.; Kiely, M. Estimation of the dietary requirement for vitamin D in healthy adults. Am. J. Clin. Nutr. 2008, 88, 1535-1542.

21. Cashman, K.D.; Wallace, J.M.; Horigan, G.; Hill, T.R.; Barnes, M.S.; Lucey, A.J.; Bonham, M.P.; Taylor, N.; Duffy, E.M.; Seamans, K.; Muldowney, S.; Fitzgerald, A.P.; Flynn, A.; Strain, J.J.; Kiely, M. Estimation of the dietary requirement for vitamin $\mathrm{D}$ in free-living adults $>=64 \mathrm{y}$ of age. Am. J. Clin. Nutr. 2009, 89, 1366-1374.

22. Genaro, P.S.; Pereira, G.A.P.; Pinheiro, M.M.; Szjenfeld, V.L.; Martini, L.A. Relationship between nutrient intake and vitamin D status in osteoporotic women. Int. J. Vitam. Nutr. Res. 2007, 77, 376-381.

23. Peters, B.S.E.; Santos, L.C.; Fisberg, M.; Martini, L.A. Prevalence of vitamin D insufficiency in Brazilian Adolescents. Ann. Nutr. Metab. 2009, 54, 15-21.

24. Lewington, S.; Clarke, R.; Qizilbash, N.; Peto, R.; Collins, R.; Prospective Studies Collaboration. Age-specific relevance of usual blood pressure to vascular mortality: a meta-analysis of individual data for one million adults in 61 prospective studies. Lancet 2002, 360, 1903-1913.

25. Giovannucci, E.; Liu, Y.; Hollis, B.W.; Rimm, E.B. 25-hydroxyvitamin D and risk of myocardial infarction in men: a prospective study. Arch. Intern. Med. 2008, 168, 1174-1180.

26. Melamed, M.L.; Muntner, P.; Michos, E.D.; Uribarri, J.; Weber, C.; Sharma, J.; Raggi, P. Serum 25-hydroxyvitamin $\mathrm{D}$ levels and the prevalence of peripheral arterial disease: results from NHANES 2001 to 2004. Arterioscler. Thromb. Vasc. Biol. 2008, 28, 1179-1185.

27. Kendrick, J.; Targher, G.; Smits, G.; Chonchol, M. 25-hydroxyvitamin D deficiency is independently associated with cardiovascular disease in the Third National Health and Nutrition Examination Survey. Atherosclerosis 2009, 205, 255-260.

28. Kim, D.H.; Sabour, S.; Sagar, U.N.; Adams, S.; Whellan, D.J. Prevalence of hypovitaminosis D in cardiovascular diseases (from the National Health and Nutrition Examination Survey 2001 to 2004). Am. J. Cardiol. 2008, 102, 1540-1544.

29. Pilz, S.; März, W.; Wellnitz, B.; Seelhorst, U.; Fahrleitner-Pammer, A.; Dimai, H.P.; Boehm, B.O.; Dobnig, H. Association of vitamin D deficiency with heart failure and sudden cardiac death 
in a large cross-sectional study of patients referred for coronary angiography. J. Clin. Endocrinol. Metab. 2008, 93, 3927-3935.

30. Zittermann, A.; Schleithoff, S.S.; Götting, C.; Dronow, O.; Fuchs, U.; Kuhn, J.; Kleesiek, K.; Tenderich, G.; Koerfer, R. Poor outcome in end-stage heart failure patients with low circulating calcitriol levels. Eur. J. Heart Fail. 2008, 10, 321-327.

31. Semba, R.D.; Houston, D.K.; Bandinelli, S.; Sun, K.; Cherubini, A.; Cappola, A.R.; Guralnik, J.M.; Ferrucci, L.; Relationship of 25-hydroxyvitamin D with all-cause and cardiovascular disease mortality in older community-dwelling adults. Eur. J. Clin. Nutr. 2010, 64, 203-209.

32. Reis, J.P.; von Mühlen, D.; Miller, E.R., 3rd; Michos, E.D.; Appel, L.J. Vitamin D Status and Cardiometabolic Risk Factors in the United States Adolescent Population. Pediatrics 2009, 124, e371-e379.

33. Forman, J.P.; Giovannucci, E.; Holmes, M.D.; Bischoff-Ferrari, H.A.; Tworoger, S.S.; Willett, W.C.; Curhan, G.C. Plasma 25-hydroxyvitamin D levels and risk of incident hypertension. Hypertension 2007, 49, 1063-1069.

34. Resnick, L.M.; Nicholson, J.P.; Laragh, J.H. Calcium metabolism in essential hypertension: relationship to altered renin system activity. Fed. Proc. 1986, 45, 2739-2745.

35. Burgess, E.D.; Hawkins, R.G.; Watanabe, M. Interaction of 1,25-dihydroxyvitamin D and plasma renin activity in high renin essential hypertension. Am. J. Hypertens. 1990, 3, 903-905.

36. Imaoka, M.; Morimoto, S.; Kitano, S.; Fukuo, F.; Ogihara, T. Calcium metabolism in elderly hypertensive patients: possible participation of exaggerated sodium, calcium and phosphate excretion. Clin. Exp. Pharmacol. Physiol. 1991, 18, 631-641.

37. Lind, L.; Hänni, A.; Lithell, H.; Hvarfner, A.; Sörensen, OH.; Ljunghall, S. Vitamin D is related to blood pressure and other cardiovascular risk factors in middle-aged men. Am. J. Hypertens. 1995, 8, 894-901.

38. Kristal-Boneh, E.; Froom, P.; Harari, G.; Ribak, J. Association of calcitriol and blood pressure in normotensive men. Hypertension 1997, 30, 1289-1294.

39. Kong, J.; Qiao, G.; Zhang, Z.; Liu, S.Q.; Li, Y.C. Targeted vitamin D receptor expression in juxtaglomerular cells suppresses renin expression independent of parathyroid hormone and calcium. Kidney Int. 2008, 74, 1577-1581.

40. Li, Y.C.; Qiao, G.; Uskokovic, M.; Xiang, W.; Zheng, W.; Kong, J. Vitamin D: a negative endocrine regulator of the renin-angiotensin system and blood pressure. J. Steroid Biochem. Mol. Biol. 2004, 89-90, 387-392.

41. Yuan, W.; Pan, W.; Kong, J.; Zheng, W.; Szeto, F.L.; Wong, K.E.; Cohen, R.; Klopot, A.; Zhang, Z.; Li, Y.C. 1,25-dihydroxyvitamin D3 suppresses renin gene transcription by blocking the activity of the cyclic AMP response element in the renin gene promoter. J. Biol. Chem. 2007, 282, 29821-29830.

42. Fryer, R.M.; Rakestraw, P.A.; Nakane, M.; Dixon, D.; Banfor, P.N.; Koch, K.A.; Wu-Wong, J.R.; Reinhart, G.A. Differential inhibition of renin mRNA expression by paricalcitol and calcitriol in C57/BL6 mice. Nephron Physiol. 2007, 106, 76-81.

43. Zhou, C.; Lu, F.; Cao, K.; Xu, D.; Goltzman, D.; Miao, D. Calcium-independent and $1,25(\mathrm{OH}) 2 \mathrm{D} 3$-dependent regulation of the renin-angiotensin system in 1alpha-hydroxylase knockout mice. Kidney Int. 2008, 74, 170-179. 
44. Wu-Wong, J.R.; Nakane, M.; Ma, J.; Ruan, X.; Kroeger, P.E. Elevated phosphorus modulates vitamin D receptor-mediated gene expression in human vascular smooth muscle cells. Am. J. Physiol. Renal Physiol. 2007, 293, F1592-F1604.

45. Tarcin, O.; Yavuz, D.G.; Ozben, B.; Telli, A.; Ogunc, A.V.; Yuksel, M.; Toprak, A.; Yazici, D.; Sancak, S.; Deyneli, O.; Akalin, S. Effect of vitamin D deficiency and replacement on endothelial function in asymptomatic subjects. J. Clin. Endocrinol. Metab. 2009, 94, 4023-4030.

46. Nibbelink, K.A.; Tishkoff, D.X.; Hershey, S.D.; Rahman, A.; Simpson, R.U. 1,25(OH)2-vitamin D3 actions on cell proliferation, size, gene expression, and receptor localization, in the HL-1 cardiac myocyte. J. Steroid Biochem. Mol. Biol. 2007, 103, 533-537.

47. Mancuso, P.; Rahman, A.; Hershey, S.D.; Dandu, L.; Nibbelink, K.A.; Simpson, R.U. 1,25Dihydroxyvitamin-D3 treatment reduces cardiac hypertrophy and left ventricular diameter in spontaneously hypertensive heart failure-prone $(\mathrm{cp} /+)$ rats independent of changes in serum leptin. J. Cardiovasc. Pharmacol. 2008, 51, 559-564.

48. Bodyak, N.; Ayus, J.C.; Achinger, S.; Shivalingappa, V.; Ke, Q.; Chen, Y.S.; Rigor, D.L.; Stillman, I.; Tamez, H.; Kroeger, P.E.; Wu-Wong, R.R.; Karumanchi, S.A.; Thadhani, R.; Kang, P.M. Activated vitamin D attenuates left ventricular abnormalities induced by dietary sodium in Dahl salt-sensitive animals. Proc. Natl. Acad. Sci. U S A. 2007, 104, 16810-5.

49. Gezmish, O.; Tare, M.; Parkington, H.C.; Morley, R.; Porrello, E.R.; Bubb, K.J.; Black, M.J. Maternal Vitamin D Deficiency Leads to Cardiac Hypertrophy in Rat Offspring. Reprod. Sci. 2010, 17, 168-176.

50. Zittermann, A.; Frisch, S.; Berthold, H.K.; Götting, C.; Kuhn, J.; Kleesiek, K.; Stehle, P.; Koertke, H.; Koerfer, R. Vitamin D supplementation enhances the beneficial effects of weight loss on cardiovascular disease risk markers. Am. J. Clin. Nutr. 2009, 89, 1321-1327.

51. Schleithoff, S.S.; Zittermann, A.; Tenderich, G.; Berthold, H.K.; Stehle, P.; Koerfer, R. Vitamin D supplementation improves cytokine profiles in patients with congestive heart failure: a doubleblind, randomized, placebo-controlled trial. Am. J. Clin. Nutr. 2006, 83, 754-759.

52. Sugiura, S.; Inaguma, D.; Kitagawa, A.; Murata, M.; Kamimura, Y.; Sendo, S.; Hamaguchi, K.; Nagaya, H.; Tatematsu, M.; Kurata, K.; Yuzawa, Y.; Matsuo, S. Administration of alfacalcidol for patients with predialysis chronic kidney disease may reduce cardiovascular disease events. Clin. Exp. Nephrol. 2009, 24:1-24:8.

53. LaCroix, A.Z.; Kotchen, J.; Anderson, G.; Brzyski, R.; Cauley, J.A.; Cummings, S.R.; Gass, M.; Johnson, K.C.; Ko, M.; Larson, J.; Manson, J.E.; Stefanick, M.L.; Wactawski-Wende, J. Calcium plus vitamin D supplementation and mortality in postmenopausal women: the Women's Health Initiative calcium-vitamin D randomized controlled trial. J. Gerontol. A. Biol. Sci. Med. Sci. 2009, 64, 559-567.

54. Autier, P.; Gandini, S. Vitamin D supplementation and total mortality: a meta-analysis of randomized controlled trials. Arch. Intern. Med. 2007, 167, 1730-1737.

55. Bolland, M.J.; Barber, P.A.; Doughty, R.N.; Mason, B.; Horne, A.; Ames, R.; Gamble, G.D.; Grey, A.; Reid, I.R. Vascular events in healthy older women receiving calcium supplementation: randomised controlled trial. BMJ 2008, 336, 262-266. 
56. Lind, L.; Wengle, B.; Ljunghall, S. Blood pressure is lowered by vitamin D (alphacalcidol) during long-term treatment of patients with intermittent hypercalcaemia. A double-blind, placebocontrolled study. Acta Med. Scand. 1987, 222, 423-427.

57. Pfeifer, M.; Begerow, B.; Minne, H.W.; Nachtigall, D.; Hansen, C. Effects of a short-term vitamin $\mathrm{D}(3)$ and calcium supplementation on blood pressure and parathyroid hormone levels in elderly women. J. Clin. Endocrinol. Metab. 2001, 86, 1633-1637.

58. Kimura, Y.; Kawamura, M.; Owada, M.; Oshima, T.; Murooka, M.; Fujiwara, T.; Hiramori, K. Effectiveness of 1,25-dihydroxyvitamin D supplementation on blood pressure reduction in a pseudohypoparathyroidism patient with high renin activity. Intern. Med. 1999, 38, 31-35.

59. Thierry-Palmer, M.; Cephas, S.; Muttardy, F.F.; Al-Mahmoud, A. High dietary cholecalciferol increases plasma 25-hydroxycholecalciferol concentration, but does not attenuate the hypertension of Dahl salt-sensitive rats fed a high salt diet. J. Steroid Biochem. Mol. Biol. 2008, 111, 7-12.

(C) 2010 by the authors; licensee Molecular Diversity Preservation International, Basel, Switzerland. This article is an open-access article distributed under the terms and conditions of the Creative Commons Attribution license (http://creativecommons.org/licenses/by/3.0/). 